\title{
EVALUASI NILAI BIOLOGIS PAKAN LENGKAP BERBASIS TEBON JAGUNG DAN RUMPUT CAMPURAN TERHADAP KINERJA PRODUKSI SAPI PERANAKAN ONGOLE (PO)
}

\author{
Yohannis L.R. Tulung*, A.F. Pendong, B. Tulung
}

Fakultas Peternakan Universitas Sam Ratulangi Manado, 95115

\begin{abstract}
ABSTRAK
Penelitian ini bertujuan untuk mendapatkan formula pakan lengkap yang efektif untuk produktivitas sapi potong (PO). Penelitian ini terdiri dari dua tahap percobaan, yaitu percobaan in vitro, dan eksperimen biologis (in vivo). Analisis statistik pada percobaan ini menggunakan uji-t dua sampel dengan asumsi varians berbeda. Perlakuan terdiri dari: Pakan RA $=50 \%$ konsentrat $+50 \%$ hijauan jagung; Pakan $\mathrm{RB}=50 \%$ konsentrat $+50 \%$ rumput campuran, masing-masing diulang 10 kali. Uji in vitro digunakan untuk mengukur kecernaan bahan kering (KCBK) dan kecernaan bahan organik (KCBO) dan konsentrasi NH3. Experimen biologis (in vivo) digunakan 20 ekor ternak sapi PO, usia 12-18 bulan, dengan bobot 120 - 180 $\mathrm{kg}$ untuk mengukur konsumsi pakan, kecernaan nutrien (bahan kering, bahan organik, protein dan energi) dan pertambahan berat badan serta konversi pakan. Hasil penelitian menunjukkan bahwa $\mathrm{KCBK}$ dan $\mathrm{KCBO}$ in vitro $\mathrm{RA}$ $67,88 \%$ dan $66,06 \%$ lebih rendah dari KCBK dan KCBO yang diperoleh di RB $71,15 \%$ dan $69,08 \%$. NH3 RA lebih tinggi dari RB, yaitu: 3,20 vs $2,50 \mathrm{mM} / \mathrm{L}$. Pada experimen biologis (in vivo), $\mathrm{KCBK}$, $\mathrm{KCBO}, \mathrm{KCP}$, dan KE perlakuan RA adalah $77,05 \%, 78,64 \%, 82,13 \%$, dan $83,48 \%$, lebih rendah dibandingkan dengan RB yaitu $80,15 \%, 83,44 \%, 85,55 \%$, dan $87,46 \%$. Pada pertambahan bobot hidup RA
\end{abstract}

*Korespondensi (corresponding Author)

Email: tulungyohannis@gmail.com menghasilkan 0,60 kg/ekor/hari lebih rendah dari RB yang menghasilkan 0,65 $\mathrm{kg}$ /ekor/hari. FCR dari kedua ransum adalah 0,11. Dapat disimpulkan bahwa pakan lengkap yang berbasis hijauan tebon jagung dan rumput campuran dapat digunakan sebagai pakan standar untuk penggemukan sapi potong lokal karena mampu memenuhi kecernaan nutrien yang tinggi dan nilai konversi pakan yang baik.

Kata Kunci: Pakan komplit, kecernaan in vitro and in vivo, pertambahan bobot, konversi pakan

\section{ABSTRACT}

EVALUATION OF

BIOLOGICAL VALUE OF COMPLETE FEED BASED ON CORN COB AND MIXED GRASS ON PRODUCTION PERFORMANCE OF ONGOLE. This study was aimed to obtain the feed formula, which is effective on the productivity of beef cattle (PO). This study consisted of two experimental stages, namely: 1). In vitro experiment, and 2). Biological (in vivo) experiment. t-test two sample assuming unequal variance was used as the statistical analysis on both experiments. The treatments of this research consisted of RA feed $=50 \%$ concentrate $+50 \%$ corn forage and $\mathrm{RB}$ feed $=50 \%$ concentrate $+50 \%$ mixed grass, and it was repeated 10 times. In vitro test was used to measure dry matter and organic 
matter digestibility and $\mathrm{NH}_{3}$ concentration $\left(\mathrm{NH}_{3}\right)$. The biological experiment (in vivo) was used 20 PO cattles, 12-18 months of ages, with 120 - $180 \mathrm{~kg}$ of body weight to measure feed intake, nutrients digestibility DMD, OMD, Protein and energy digestibility, live weight gain (LWG) and feed conversion (FCR). The results showed $\mathrm{DMD}$ and OMD in vitro of RA were $67.88 \%$ dan $66.06 \%$, respectively, lower than the DMD and OMD obtained in RB, i.e $71.15 \%$ dan $69.08 \%$, respectively. Meanwhile, $\mathrm{NH}_{3}$ of $\mathrm{RA}$ was higher than RB, i.e: 3.20 vs $2.50 \mathrm{mM} / \mathrm{L}$. The biological experiment showed the DMD, OMD, CPD, and $\mathrm{DE}$ (in vivo) of RA were $77.05 \%$, $78.64 \%, 82.13 \%$, and $83.48 \%$, respectively, while the results obtained at RB were higher, i.e. $80.15 \%, 83.44 \%, 85.55 \%$, and $87.46 \%$, respectively. On the liveweight gain (LWG) of PO cattle, the RA ration produces $0.60 \mathrm{~kg}$ per head per day, lower than RB which produces $0.65 \mathrm{~kg}$ per head per day. The FCR of both ration was 0.11 . It is concluded, complete feed based on forage corn and mixed grass can be used as standard feed for fattening of local beef cattle because it is able to give high nutrient digestibility and good feed conversion value

Keywords: Complete feed, in vitro and in vivo digestibility, liveweight gain, feed conversion

\section{PENDAHULUAN}

Pertumbuhan ekonomi nasional berdampak langsung pada peningkatan pendapatan perkapita penduduk, dimana keberhasilan tersebut ternyata berpengaruh pada perubahan konsumsi masyarakat yang semula lebih banyak mengkonsumsi karbohidrat, mulai bergeser ke arah konsumsi pangan sumber sumber gizi protein hewani, seperti daging, telur dan susu. Hal ini, menyebabkan meningkatnya permintaan dan konsumsi daging, termasuk daging sapi. Namun, kenyataannya, sekarang ini produksi daging sapi belum mampu mengimbangi laju permintaan dalam negeri. Kondisi tersebut melahirkan kebijakan importasi sapi bakalan dan daging sapi untuk menutup kesenjangan suplai dan permintaan.

Adanya kesenjangan produksi daging dan kebutuhan dalam negeri secara nasional dan Sulawesi Utara pada khususnya, bukan berarti bahwa Indonesia belum memiliki ataupun menerapkan teknologi di bidang peternakan yang mumpuni. Fenomena di atas kemungkinan lebih disebabkan oleh strategi dan kebijakan pemerintah baik pusat maupun di daerah yang belum tepat sasaran pada perimbangan pemenuhan kebutuhan antara pangan berbasis karbohidrat dan sumber pangan asal ternak, yang mungkin masih dianggap belum merupakan komoditas strategis. Padahal, pembangunan peternakan sebagai bagian dari pembangunan pertanian selalu terkait dengan reorientasi kebijakan pembangunan pertanian dalam mewujudkan ketahanan pangan nasional. Oleh karena itu, perlu 
dukungan strategis melalui penelitian pengembangan ilmu pengetahuan dan teknologi inovasi dibidang ketahanan pangan yang komprehensif, sistematis, berdaya saing dan berkelanjutan.

$$
\text { Pengembangan sapi potong }
$$
memiliki posisi strategis dalam konteks pembangunan ketahanan pangan nasional. Karena ternak sapi potong merupakan salah satu kontributor terbesar produksi daging nasional, mengingat 98 persen penyediaan sapi potong dan daging sapi dalam negeri selama ini berbasis peternakan rakyat. Berdasarkan sensus pertanian 2013 (ST 2013), tercatat ada 5.079.000 rumah tangga peternak (RTP) yang menguasai lebih dari 98 persen ternak sapi potong di Indonesia dimana menjadi sebuah keniscayaan jika peternakan sebagai lokomotif pembangunan pertanian. Karena itu, ternak sapi lokal yang selama ini dikembangkan di Indonesia, sudah selayaknya dijadikan basis pemenuhan kebutuhan daging nasional dalam rangka perwujudan ketahanan pangan nasional.

Sapi potong tergolong jenis herbivora yang pakan utamanya adalah hijauan, baik jenis rumput (graminae), ataupun jenis legum dengan berbagai macam ragamnya, termasuk dedaunan dari jenis-jenis tanaman tertentu. Ini bukan berarti ruminansia tidak bisa makan jenis pakan sereal dari biji-bijian ataupun sumber-sumber karbohidrat dari jenis tanaman umbi-umbian. Semuanya bisa dimakan, tetapi yang menempati proporsi terbesar dan merupakan prinsip dalam pemberian pakan untuk ruminansia adalah hijauan.

Di Indonesia sumber daya hijauan pakan terbilang melimpah, tersedia sepanjang tahun dan tersebar hampir diseluruh daerah. Ironisnya, potensi tersebut tidak diimbangi dengan produktivitas sapi potong. Karena tak dapat disangkal, bahwa perkembangan hijauan di daerah topis secara fisiologis sangat dipengaruhi oleh kondisi musim penghujan dan kemarau, disamping pola budidaya konvensional yang berlaku di tingkat peternakan rakyat. Di daerah tropis yang mengalami musim hujan dan kemarau, peralihan fase tumbuh hijauan pakan dari vegetatif ke fase pertumbuhan generatif (reproduktif) berlangsung cepat. Perbedaan fase tumbuh hijauan, menyebabkan perbedaan pada segi kualitas nutrien yang terkandung. Ketika hijauan memasuki fase tumbuh generatif, hijauan pakan cenderung menghasilkan serat kasar yang tinggi, sementara kandungan nutrien yang penting justeru menurun. Konsekuensi logis yang dihadapi peternak adalah membiarkan ternak mengais gizi secukupnya dari hijauan berkualitas rendah, sekedar untuk hidup pokok. Tidak heran, jika usaha peternakan sapi potong di kebanyakan daerah di Indonesia termasuk Sulawesi 
Utara, kinerja produksinya terbilang rendah, karena terjebak pada pola budidaya konvensional yang selalu berhadapan dengan kendala klasik, yaitu tingkat kecukupan gizi pakan masih di bawah standar kebutuhan. Sementara, kalaupun ada sumber pakan lokal berkualitas yang bisa dioptimalkan pemanfaatannya, sering tersendung dengan kebutuhan kompetitor, seperti manusia ataupun jenis ternak lainnya (seperti ternak monogastrik). Apalagi, ketersediaan lahan untuk improvisasi kebun rumput atau padang penggembalaan semakin terjepit diantara kebutuhan lahan untuk tanaman pangan dan lahan untuk pemukiman.

Hijauan pakan yang umumnya tersebar di Indonesia, khususnya yang tergolong jenis-jenis rumput (graminae), antara lain: rumput para (brachiaria mutica), rumput raja (pennisetum purpupoides), rumput gajah (pennisetum purpureum), benggala (panicum maximum), dan rumput lapang, termasuk sorghum dan tebon jagung, memiliki kandungan nutrien terutama protein berkisar $8-11$ persen (Heuze dan Tran 2015). Bagi kebutuhan produksi sapi potong, pemberian pakan rumput saja memerlukan waktu yang cukup panjang untuk mencapai pertumbuhan dan produksi optimal. Pendekatan teknologi inovatif yang memungkinkan efektifitas pertumbuhan dan produksi, yaitu melalui aplikasi pakan lengkap berbasis hijauan menggunakan pakan penguat, melalu teknik formulasi all in one ration, dimana dengan teknik tersebut akan berlangsung efek asosiatif atau efek saling melengkapi antara komponen-komponen nutrien pakan dalam hijauan rumput dengan pakan penguat, yang pada gilirannya tercapainya pemenuhan gizi dan produksi ternak sapi potong.

Berdasarkan uraian di atas, maka dilakukan penelitian tentang evaluasi nilai biologis pakan lengkap berbasis tebon jagung dan rumput campuran terhadap kinerja produksi sapi potong peranakan ongole (PO).

\section{MATERI DAN METODE PENELITIAN}

Penelitian ini diarahkan dalam dua tahapan percobaan, dimulai dari pemilihan, identifikasi dan karakterisasi bahan-bahan pakan melalui analisis proksimat, kemudian formulasi 2 (dua) jenis pakan lengkap (RA dan RB), yang dijadikan objek percobaan pengujian kecernaan pakan in vitro pada tahap I. Pada tahapan lebih lanjut, dilakukan pengujian biologis melalui aplikasi pakan pada ternak sapi potong (feeding trial), untuk mengetahui nilai biologis kedua pakan lengkap, yaitu kecernaan nutrient pakan in vivo dan pengaruh biologis pakan tersebut pada 
pertambahan bobot badan sapi potong.

\section{Penelitian Tahap I}

Untuk mengetahui potensi zat-zat nutrien pakan lengkap dalam menunjang aktivitas mikroba rumen, dimana nilai koefisien cerna nutrient in vitro, menjadi indikator dalam memprediksi pengaruhnya dalam uji biologis pada sapi PO. Materi penelitian dalam tahap ini adalah 2 (dua) jenis pakan lengkap, terdiri dari pakan $\mathrm{RA}=50 \%$ pakan penguat $+50 \%$ tebon jagung; $\mathrm{RB}=50 \%$ pakan penguat + $50 \%$ rumput campuran dengan komposisi nutrient dapat dilihat pada Tabel 1 . Penggunaan 50\% baik untuk pakan penguat maupun pakan hijauan, didasarkan pada kebutuhan ternak sapi potong dengan bobot badan rata-rata $300 \mathrm{~kg}$, dengan kebutuhan bahan kering 7 kg (Rayburn, 2009; diadaptasi dari NRC 2000). Sehingga jumlah penggunaan konsentrat dalam pakan komplit, baik pakan RA maupun RB adalah sebesar $50 \%$ x $7 \mathrm{~kg}=3,5 \mathrm{~kg}$, dan bagian $50 \%$ lainnya dipenuhi oleh rumput raja pada perlakuan RA dan rumput campuran pada pelakuan RB pada kisaran jumlah pemberian 24 - 30 gram segar. Kedua jenis pakan ini akan diuji secara in vitro menggunakan teknik dua tahap (two stages Tilley and Terry Technique), untuk mendapatkan nilai kecernaan nutrien in vitro dari masing-masing perlakuan. Snedecor and Cochran (1989).

Peralatan yang digunakan antara lain: Inkubator, syringe, waterbath $39^{\circ} \mathrm{C}$, termometer, erlemeyer $200 \mathrm{~mL}$, pipet piston, timbangan analitis, crucible, beaker glass, kertas saring, tabung sentrifuse, oven $105^{\circ} \mathrm{C}$ dan tanur $550^{\circ} \mathrm{C}$, dan termos, kain saring, kertas saring whatman dan alat lain untuk uji in vitro.

Bahan yang digunakan, antara lain: bahan untuk uji kecernaan in vitro yaitu cairan rumen, larutan buffer, larutan mineral makro, larutan mineral mikro, dan $\mathrm{HCl}+$ pepsin, dua jenis pakan yang akan di uji, terdiri dari 20 sampel dengan berat setiap sampel rata-rata 0,5 gram.

\section{Metode Penelitian}

Metode statistik yang digunakan dalam penelitian ini adalah $\mathrm{Uji} \mathrm{t}$ dua contoh dengan ragam tidak sama (t-test two sample assuming unequal varience) (Snedecor dan Cochran, 1989; Derrick et al. 2017).

Percobaan ini terdiri dari 2 (dua) perlakuan dan 10 ulangan, dimana penempatan perlakuan dilakukan secara acak. Bagan percobaan disajikan pada Tabel 2. Dengan analisis data menggunakan uji $t$, dengan formulasi sebagai berikut: 


$$
t=\frac{\bar{x}_{1}-\bar{x}_{2}}{\sqrt{\frac{\sigma_{1}^{2}}{n_{1}}+\frac{\sigma_{2}^{2}}{n_{2}}}}
$$

dimana :

$\mathrm{t}=\mathrm{t}$ statistik

$\bar{x}_{1}$ dan $\bar{x}_{2}=$ rataan hasil dari dua contoh perlakuan

$\sigma^{2}{ }_{1}$ dan $\sigma^{2}{ }_{2}=$ keragaman dari hasil kedua contoh perlakuan.

$\mathrm{n}_{1}$ dan $\mathrm{n}_{2}=$ jumlah pengamatan dari 2 perlakuan

$\mathrm{t}$ - statistik mengikuti suatu distribusi $\mathrm{t}$, dengan perkiraan derajat bebas (df), sebagai berikut:

$$
d f=\frac{\left(\sigma^{2}{ }_{1} / n_{1}+\sigma^{2}{ }_{2} / n_{2}\right)^{2}}{\left(\sigma^{2}{ }_{1} / n_{1}\right)^{2} /\left(n_{1}-1\right)+\left(\sigma^{2}{ }_{2} / n_{2}\right) /\left(n_{2}-1\right)}
$$

Peubah yang diukur untuk penelitian in vitro terdiri dari kecernaan bahan kering, kecenaan bahan organik dan konsentrasi Ammonia (NH3).

\section{Penelitian Tahap II}

Penelitian tahap II merupakan lanjutan dari penelitian tahap I yang bertujuan untuk mengetahui pengaruh potensi zat-zat nutrien pakan lengkap dalam menunjang kebutuhan ternak. Materi penelitian dalam tahap ini adalah: 20 ekor sapi PO, berumur 18 - 24 bulan dengan bobot antara 180 $250 \mathrm{~kg}$. Dua jenis pakan lengkap, terdiri dari pakan $\mathrm{RA}=50 \%$ pakan penguat +
$50 \%$ tebon jagung; $\mathrm{RB}=50 \%$ pakan penguat $+50 \%$ rumput campuran. Komposisi nutrien dapat dilihat pada Tabel 1. Penggunaan $50 \%$ baik untuk pakan penguat maupun pakan hijauan, didasarkan pada kebutuhan ternak sapi potong dengan bobot badan rata-rata 300 $\mathrm{kg}$, dengan kebutuhan bahan kering $7 \mathrm{~kg}$ (Rayburn, 2009; diadaptasi dari NRC 2000). Sehingga jumlah penggunaan konsentrat dalam pakan komplit, baik pakan RA maupun RB adalah sebesar 50\% x $7 \mathrm{~kg}=3,5 \mathrm{~kg}$, dan bagian 50\% lainnya dipenuhi oleh rumput raja pada perlakuan RA dan rumput campuran pada pelakuan RB pada kisaran jumlah pemberian $24-30$ gram segar. Kedua jenis pakan ini akan diuji secara biologis untuk mendapatkannilai kecernaan nutrien in vivo dari masing-masing perlakuan, dan juga pertambahan bobot badan sapi PO

Peralatan yang digunakan antara lain kandang individual ternak dilengkapi tempat makan dan minum, timbangan pakan, chopper, timbangan ternak, pita ukur, sekop, kantong plastik, dan lain-lain.

Bahan yang digunakan, antara lain: Bahan pakan untuk formulasi pakan penguat, terdiri dari jagung, kadele, dedak halus, tepung ikan, premix, garam, tebon jagung dan rumput campuran (rumput para, rumput benggala, dan rumput gajah. 
Tabel 1. Komposisi nutrien pakan perlakuan

\begin{tabular}{lccc}
\hline \multirow{2}{*}{ Nutrien *) } & Konsentrat & $\begin{array}{c}\text { Tebon Jagung } \\
(\mathrm{TJ})\end{array}$ & $\begin{array}{c}\text { Rumput } \\
\text { Campuran }\end{array}$ \\
\cline { 2 - 4 } & \multicolumn{3}{c}{ \% } \\
\hline Bahan Kering & 87,93 & 21,27 & 23,60 \\
Bahan Organik & 76,03 & 17,46 & 19,46 \\
Protein & 16,65 & 10,90 & 10,30 \\
Lemak Kasar & 5,28 & 2,17 & 2,08 \\
Serat Kasar & 11,23 & 33,21 & 34,66 \\
NDF & 27,23 & 69,81 & 70,45 \\
ADF & 14,39 & 40,20 & 41,05 \\
Ca & 0,73 & 0,39 & 0,38 \\
P & 1,82 & 0,23 & 0,26 \\
Abu & 11,90 & 10,67 & 10,20 \\
BETN & 42,87 & 44,05 & 42,77 \\
Energi Bruto (Kkal) & 3708,89 & 3791,00 & 3571,00 \\
\hline
\end{tabular}

*) Sumber: Lab. Minat Nutrisi dan Makanan Ternak Fak. Peternakan UB (2019)

\section{Metode Penelitian}

Metode penelitian yang digunakan dalam penelitian ini metode eksperimen dengan menggunakan Uji $t$ dua contoh dengan ragam tidak sama (t-test two sample assuming unequal varience) (Snedecor and Cochran, 1989; Derrick, et al., 2017). Percobaan ini terdiri dari 2 (dua) perlakuan dan 10 ulangan, dimana penempatan perlakuan dilakukan secara acak. Peubah yang diukur pada penelitian tahap II (in vivo) terdiri dari kecernaan bahan kering, kecenaan bahan organik, kecernaan protein, kecernaan energi dengan menggunakan formulasi:

$\mathrm{K}=\frac{\text { Nutrien yang dikonsumsi }- \text { Nutrien feses }}{\text { Nutrien yang dikonsumsi }} \times 100 \%$

Pertambahan Bobot badan (g/hari) dihitung menurut formulasi
$\mathrm{PBB}=\frac{W 2-W 1}{t}$

$\mathrm{W} 1$ = berat awal; $\mathrm{W} 2=$ berat akhir; $\mathrm{t}=$ waktu pemeliharaan

\section{HASIL DAN PEMBAHASAN}

\section{Kecernaan nutrien in vitro pakan lengkap sapi PO berbasis tebon jagung dan rumput campuran}

Teknik dua tahap Tilley and Terry (1963) (two stages Tilley and Terry Technique) digunakan dalam percobaan untuk mengukur kecernaan bahan kering dan bahan organic dua jenis pakan lengkap sapi peranakan ongole PO, yaitu: perlakuan $50 \%$ pakan penguat $+50 \%$ tebon jagung (RA) dan perlakuan 50\% pakan penguat $+50 \%$ rumput campuran 
Tabel 2. Kandungan bahan kering dan bahan organik pakan lengkap berbasis tebon jagung dan pakan lengkap berbasis rumput campuran

\begin{tabular}{ccc}
\hline \multirow{2}{*}{ Komponen kimiawi (\%) } & \multicolumn{3}{c}{ Perlakuan } \\
\cline { 2 - 3 } & RA & RB \\
\hline Bahan Kering (BK) & 86,13 & 87,08 \\
Bahan Organik (BO) & 72,17 & 71,71 \\
\hline
\end{tabular}

(RB). Adapun kandungan bahan kering dan bahan organik dari kedua perlakuan pakan lengkap RA dan RB disajikan dalam Tabel 2. 7 kg (Rayburn, 2009; diadaptasi dari NRC 2000). Sehingga jumlah penggunaan konsentrat dalam pakan komplit, baik pakan RA maupun RB adalah sebesar $50 \%$ x $7 \mathrm{~kg}=3,5 \mathrm{~kg}$, dan bagian 50\% lainnya dipenuhi oleh rumput raja pada perlakuan RA dan rumput campuran pada pelakuan RB pada kisaran jumlah pemberian 24 - 30 gram segar. Kedua jenis pakan ini akan diuji secara biologis untuk mendapatkan nilai kecernaan nutrien in vivo dari masingmasing perlakuan, dan juga pertambahan bobot badan sapi PO.

Peralatan yang digunakan antara lain kandang individual ternak dilengkapi tempat makan dan minum, timbangan pakan, chopper, timbangan ternak, pita ukur, sekop, kantong plastik, dan lain-lain.

Bahan yang digunakan, antara lain: Bahan pakan untuk formulasi pakan penguat, terdiri dari jagung, kadele, dedak jagung dan rumput campuran (rumput para, rumput benggala, dan rumput gajah.

\section{Kecernaan bahan kering dan bahan organik in vitro}

Kecernaan bahan kering (KCBK) dan kecernaan bahan organik (KCBO) dari perlakuan RA dan perlakuan $50 \%$ pakan penguat $+50 \%$ rumput campuran $(\mathrm{RB})$ disajikan pada Tabel 7. Hasil uji statistik, menunjukkan bahwa kecernaan KCBK dan $\mathrm{KCBO}$ in vitro pakan lengkap berbasis tebon jagung (RA) berbeda nyata lebih rendah dari pada perlakuan berbasis rumput campuran (RB). Nilai kecernaan erat kaitannya dengan komposisi kimiawi yang terkandung dalam pakan tersebut. (McDonald et al., 2010). Ditinjau dari komposisi kimiawi bahan pakan yang digunakan (Tabel 2), kandungan bahan kering pakan RB sedikit lebih tinggi dari, pakan RA, namun sebaliknnya kandungan bahan organik pakan RA sedikit lebih tinggi dari pakan RB. Namun, dari nilai koefisien cernanya secara in vitro ternyata 
Tabel 3. Kecernaan baahan kering, bahan organik dan konsentrasi $\mathrm{NH}_{3}$ pakan percobaan

\begin{tabular}{|c|c|c|}
\hline \multirow{2}{*}{ Komponen kimiawi } & \multicolumn{2}{|c|}{ Perlakuan } \\
\hline & RA & RB \\
\hline $\operatorname{KCBK~}(\%)$ & $67,88^{a}$ & $71,15^{b}$ \\
\hline $\mathrm{KCBO}(\%)$ & $66,06^{\mathrm{a}}$ & $69,08^{b}$ \\
\hline Konsentrasi $\mathrm{NH}_{3}(\mathrm{mM} / \mathrm{L})$ & $3,20^{\mathrm{b}}$ & $2,50^{\mathrm{a}}$ \\
\hline
\end{tabular}

Keterangan: Superskrip yang berbeda dalam baris yang sama menunujukkan perbedaan Nyata $(\mathrm{P}<0,05)$

komponen bahan kering dan bahan organik pakan RB diasumsikan lebih banyak diserap dalam tubuh ternak. Variasi perbedaan dalam nilai kecernaan in vitro, disebabkan oleh bervariasinya sumbersumber bahan pakan yang digunakan baik dalam susunan konsentrat, maupun sumber-sumber hijauan rumput, sehingga efek asosiasi dari komponen kimiawi dari setiap bahan pakan dalam proses fermentasi mikroba cairan rumen menjadi berbeda. Menurut Orskov (1992) suhu, pH, kapasitas buffer, tekanan osmotik, kandungan bahan kering dan potensial reduksi-oksidasi merupakan faktor-faktor utama yang mempengaruhi pertumbuhan, aktivitas dan populasi mikroba rumen.

\section{Konsentrasi ammonia $\left(\mathrm{NH}_{3}\right)$ in vitro}

Nilai konsentrasi $\mathrm{NH}_{3}$ dari pakan percobaan RA dan RB, masing-masing 3,2 $\mathrm{mM} / 1$ dan 2,5 mM/liter. Analisis statistik, menunjukkan nilai konsentrasi $\mathrm{NH}_{3}$ pakan RA berbeda nyata $(\mathrm{P}<0,05)$ lebih tinggi dari RB. Konsentrasi ammonia in vitro hasil penelitian ini berada dalam jarak variasi konsentrasi yang dikemukakan Schmidt and Zsedely (2011), yaitu 2-20 mM/L. Disampaikan, ada beberapa faktor yang menyebabkan lebarnya variasi konsentrasi ammonia, antara lain: tingkat degradasi pakan dalam rumen, jumlah protein pakan, juga waktu retensi pakan dalam rumen. Konsentrasi ammonia in vitro dalam penelitian ini, variasinya cukup sempit $(2,5$ - 3,2 mM/L), hal ini disebabkan oleh kandungan bahan kering dan bahan organik kedua pakan percobaan (Tabel 2) hampir sama. Lagipula, berat sampel pakan percobaan yang digunakan dalam percobaan in vitro adalah rata-rata sama, yaitu 0,5 g. Adanya perbedaan dimana konsentrasi ammonia pakan RA lebih tinggi dari RB, diduga disebabkan oleh kandungan protein dalam tebon jagung dalam pakan komplit RA lebih muda terdegradasi dibanding protein dalam rumput campuran. Produk utama fermentasi mikroba terhadap protein pakan dalam rumen adalah ammonia. Jumlah konsentrasi ammonia yang diproduksi dalam rumen berbanding lurus dengan 
jumlah protein pakan yang mengalami degradasi oleh mikroba rumen. Beberapa sumber menyatakan, populasi mikroba dalam rumen memiliki kapasitas proteolitik yang tinggi (Ørskov, 1992; dan Nolan dan Dobos, 2005). Schmidt dan Zsedely (2011) mengatakan, Proses proteolitik atau penguraian protein oleh enzim-enzim mikroba dan juga sintesis protein mikroba terjadi secara bersamaan di pra-lambung ruminansia. Sejalan dengan itu Nolan and Dobos (2005) menyatakan bahwa mikroba rumen memiliki kemampuan untuk melakukan sintesis de novo asam-asam amino essensial untuk pembentukan jaringan tubuh hewan inang, dimana sintesis in menggunakan produk-produk ammonia dan kerangka karbon yang diproduksi selama proses degradasi pakan.

Ammonia (NH3) merupakan perantara tengah dalam degradasi $\mathrm{N}$ dan asimilasinya dalam rumen (Rodríguez et al., 2007). Dilaporkan, kadar ammonia dalam rumen berkisar 0 -130 mg N/100 mL, tergantung pada sumber-sumber protein pakan dan waktu ternak makan (postprandial time). Menurut Nolan dan Dobos (2005) konsentrasi kompleks ammonia dapat melebihi angka-angka tersebut, setelah hewan makan hijauan segar. Kadar ammonia N yang diperoleh dalam penelitian ini antara 2,5-3,2 $\mathrm{mM} / \mathrm{L}$, jika dikonversi dalam nilai mg N/100 mL menjadi 45,1 - 57,7 mg N/100 mL, yang berarti produk ammonia dalam penelitian ini berada dalam kisaran normal. Satter and Slyter (1974) menyatakan penimbunan ammonia di rumen melebihi kadar $5 \mathrm{mg}$ $\mathrm{NH}, \mathrm{N} / 100 \mathrm{~mL}$ cairan rumen, tidak ada hasil yang diperoleh dengan suplementasi $\mathrm{N}$ bukan protein (non protein nitrogen). Dikatakan, bahwa dengan konsentrasi ammonia $5 \mathrm{mg} \mathrm{NH}, \mathrm{N} / 100 \mathrm{~mL}$ tersebut sudah cukup untuk mendukung tingkat pertumbuhan maksimum bakteri rumen. Sementara sebelumnya Ørskov et al. (1972) menemukan bahwa pertumbuhan mikroba maksimum pada saat kadar $\mathrm{NH}_{3}, \mathrm{~N}$ berada pada kisaran $4-8 \mathrm{mg} 100 \mathrm{~mL}$ cairan abomasum. Van Soest (1994), juga mengemukakan konsentrasi optimum $\mathrm{N}$ ammonia untuk sintesa protein mikroba dalam rumen adalah antara 5,6 - $10 \mathrm{mg}$ $\mathrm{NH} 3 / 100 \mathrm{~mL}$ cairan rumen, ketika ketersediaan energi tidak membatasi ekosistem rumen. Kadar tersebut hampir sama dengan yang dilaporkan Sutardi (2003), yaitu antara 4,8 - 8,1 mg/100 mL. Dengan kadar ammonia $2,5-3,2 \mathrm{mM} / \mathrm{L}$ atau 45,1 - 57,7 mg N/100 mL yang diperoleh dalam penelitian ini, berarti sumber $\mathrm{N}$ yang diperlukan untuk mendukung sintesa protein mikroba dalam rumen sudah sangat tercukupi. Di antara faktor-faktor yang mempengaruhi sintesis protein mikroba, ketersediaan dan sinkronisasi antara energi dan Senyawa nitrogen $(\mathrm{N})$ dalam rumen menjadi faktor 
terpenting. Meski faktor-faktor terpenting lainnya seperti pakan, biologis dan kimiawi dapat mempengaruhi efisiensi sintesis protein mikroba di rumen (Pathak, 2008)

Uji biologis pakan lengkap sapi PO berbasis tebon jagung dan rumput campuran

Dalam uji biologis, percobaan dilakukan untuk mengukur pertambahan bobot badan dan kecernaan nutrient pakan in vivo. Rataan konsumsi ternak sapi PO terhadap komponen-komponen kimiawi pakan perlakuan, meliputi: bahan kering, bahan organik, protein dan energi, baik pada tahap pemeliharaan untuk pengukuran bobot badan, maupun pada tahap pengukuran kecernaan disajikan dalam Table 4. Kecernaan nutrien pakan yang terdiri dari kecernaan bahan kering (KCBK), kecernaan bahan organic (KCBO), kecernaan protein kasar (KCP) dan kecernaan energi (KE), merepresentasikan potensi suatu bahan pakan atau ransum pakan melalui nilai koefisien dari setiap komponen nutrient pakan yang tertinggal dalam saluran cernayang kemudian digunakan dalam proses tubuh ternak. Pengaruh perlakuan pakan lengkap terhadap KCBK, KCBO,

Tabel 4. Rataan konsumsi nutrien pakan

\begin{tabular}{lccccc}
\hline & & \multicolumn{4}{c}{ Komponen Kimiawi } \\
\cline { 3 - 6 } Variable Pengukuran & Perlakuan & $\begin{array}{c}\text { Bahan } \\
\text { Kering } \\
(\mathrm{kg})\end{array}$ & $\begin{array}{c}\text { Bahan } \\
\text { organik } \\
(\mathrm{kg})\end{array}$ & $\begin{array}{c}\text { Protein } \\
\text { Kasar } \\
(\mathrm{kg})\end{array}$ & $\begin{array}{c}\text { Energi } \\
(\mathrm{Kkal} / \mathrm{kg})\end{array}$ \\
\hline \multirow{2}{*}{ Kecernaan in vivo } & RA & 5,78 & 2,81 & 0,81 & 3747,28 \\
& RB & 6,20 & 2,92 & 0,83 & 3639,39 \\
\hline \multirow{2}{*}{ Pertambahan berat badan } & RA & 5,39 & 2,74 & 0,76 & 3774,08 \\
& RB & 5,77 & 2,84 & 0,79 & 3644,58 \\
\hline
\end{tabular}

Tabel 5. Rataan kecernaan nutrien pakan in vivo

\begin{tabular}{lcc}
\hline \multirow{2}{*}{ Komponen Kimiawi (\%) } & \multicolumn{2}{c}{ Perlakuan } \\
\cline { 2 - 3 } & RA & RB \\
\hline KCBK & $77,05^{\mathrm{b}}$ & $80,15^{\mathrm{a}}$ \\
KCBO & $78,64^{\mathrm{b}}$ & $83,44^{\mathrm{a}}$ \\
$\mathrm{KCP}$ & $82,13^{\mathrm{b}}$ & $85,55^{\mathrm{a}}$ \\
KE & $83,48^{\mathrm{b}}$ & $87,46^{\mathrm{a}}$ \\
\hline
\end{tabular}

Keterangan: Superskrip yang berbeda pada baris yang sama menunjukkan perbedaan nyata $(\mathrm{P}<0,05)$ 
$\mathrm{KCP}$ dan KE in vivo disajikan pada Tabel 5.

\section{Kecernaan bahan kering dan bahan organik in vivo}

Analisis statistik menunjukkan, kecernaan bahan kering pakan komplit RA berbeda nyata $(\mathrm{P}<0,05)$ lebih rendah dari pakan RB, sementara untuk kecernaan bahan organik, pakan RA memberi hasil sangat nyata $(\mathrm{P}<0,01)$ lebih rendah dari pakan RB. Perbedaan nilai kecernaan tersebut disebabkan oleh beberapa faktor, dimana salah satu faktor yang dominan adalah jumlah konsumsi bahan kering ransum. Hasil percobaan menunjukkan, jumlah konsumsi bahan kering (Tabel 4), pakan RA mendapat respon konsumsi oleh ternak sapi lebih rendah $(5,78 \mathrm{~kg})$ dibanding pakan RB $(6,20 \mathrm{~kg})$, yang berarti komponen-komponen organik yang terkandung di dalamnya, seperti protein, serat kasar dan energi juga turut mendukung tingkat kecernaan pakan perlakuan tersebut. Christiyanto et al. (2005) melaporkan nilai nilai kecernaan pakan yang lebih rendah dibanding hasil penelitian ini, yaitu; masing-masing KCBK $(68,00-70,51 \%)$ dan $\mathrm{KCBO}(72,23-$ 74,74). Nilai kecernaan ini diperoleh dari percobaan pada sapi perah yang diberi ransum perlakuan berbasis rumput raja dengan proporsi konsentrat 45\%, yang mengandung precursor protein-energi berbeda. Disampaikan bahwa konsentrat yang ditambahkan pada ransum justeru memperbaiki KCBK dan KCBO rumput raja. Menurut de Carvalho et al. (2010) bahwa nilai kecernaan bahan kering dan bahan organik pada sapi PO dan sapi persilangan Simental-PO yang diberi perlakuan ransum berbasis rumput gajah, ketela pohon dan kulit kedelai dengan tingkat penggunaan konsentrat 55\%, yaitu: $\operatorname{KCBK}(67,37$ dan 68,57\%); $\operatorname{KCBO}(75,27$ dan $71,78 \%$ ). Nilai kecernaan dari laporan tersebut, terpaut lebih rendah dari hasil penelitian ini, yaitu $\operatorname{KCBK}(70,05$ dan $80,15 \%) ; \operatorname{KCBO}(78,64$ dan $83,44 \%)$ seperti tercantum pada Tabel 5. Perbedaan ini bisa disebabkan kandungan serat kasar dari bahan-bahan pakan penyusun ransum, dimana de Carvalho et al. (2010) dalam susunan ransumnya selain hijauan rumput, juga menggunakan bahan pakan penyusun, seperti: kulit kedelai dan konsentrat yang memiliki kandungan serat kasar cukup tinggi (28,9 dan 30,54\%), sementara pada penelitian ini menggunakan konsentrat dengan kandungan serat kasar hanya $11,23 \%$. Tingginya serat kasar dalam ransum pakan lengkap, akan dapat menyebabkan menurunnya derajat ketersediaan protein dan energi pakan tersebut dalam menunjang aktivitas mikroba rumen. Tinggi rendahnya kandungan serat kasar akan mempengaruhi kemampuan mikroba rumen dalam 
mencerna serat kasar sehingga mempengaruhi nilai KCBK (Van Soest, 1994).

Penggunaan konsentrat sebesar $50 \%$ dalam susunan pakan lengkap berbasis rumput raja dan rumput campuran, ternyata mampu meningkatkan nilai kecernaan KCBK dan KCBO. Kondisi ini, dimungkinkan karena konsentrat memberi kontribusi ketersediaan karbohidrat non struktural yang cukup tinggi sebagai sumber energi bagi pertumbuhan dan aktivitas mikroba rumen. Disamping itu, konsentrat memiliki kandungan protein yang memadai dalam menunjang kelengkapan nutrien pakan, dimana selain menyuplai kebutuhan $\mathrm{N}$ ammonia bagi sintesa protein mikrobial di rumen, juga sebagai sumber protein langsung bagi ternak inang, yaitu protein yang lolos degradasi rumen.

Kecernaan pakan yang tinggi menunjukkan besarnya komponen nutrien pakan tersebut yang disalurkan pada ternak, sebalikya kecernaan pakan yang lebih rendah menunjukkan lebih kurangnya komponen nutrien pakan tersebut yang bisa digunakan bagi ternak, baik untuk hidup pokok ataupun untuk produksi. Nilai koefisien cerna bahan kering menunjukkan derajat cerna pakan dalam saluran pencernaan serta seberapa besar manfaat pakan bagi ternak (McDonald et al., 2010). Kecernaan pakan pada ternak ruminansia

\section{Kecernaan protein in vivo}

Nilai kecernaan protein pakan RA (82,13\%) lebih rendah dibanding pakan RB $(85,55 \%)$. Hal ini terindikasi pada nilai KCBK dan KCBO dari kedua pakan perlakuan yang memiliki selisih masingmasing 3\% dan 5\%. Padahal nilai konsumsi protein sapi PO rata-rata per ekor per hari pada masing-masing pakan RA dan RB adalah $0,76 \mathrm{~kg}$ dan $0,79 \mathrm{~kg}$, yang berarti hanya selisih $30 \mathrm{~g}$ protein per hari. Sementara itu pada Tabel 1, nilai kandungan protein rumput tebon jagung pada pakan RA adalah $10,90 \%$, agak lebih tinggi dibanding dengan rumput campuran pada pakan RB yang hanya $10,30 \%$. Meningkatnya kecernaan protein pada pakan RB, kemungkinan karena pakan lengkap ini berbasis hijauan pakan campuran, sedangkan RA pakan lengkap dengan basis hijauan pakan tunggal (tebon jagung). Susunan ransum pakan RB yang lebih beragam sumber hijauan pakannya berpotensi terjadinya pengaruh saling melengkapi secara positif antara nutrien yang terkandung dari masing-masing sumber bahan pakan, baik antara pakan penguat dengan rumput campuran, maupun antara sumber-sumber hijauan rumput campuran. Rumput campuran dalam pakan 
$\mathrm{RB}$, terdiri dari rumput raja, rumput benggala dan rumput para. Sumber protein pakan RB yang berasal dari hijauan tebon jagung, kemungkinan lebih mudah terdegradasi dalam rumen, akibatnya lebih banyak komponen ammonia (nitrogen) yang terbuang melalui feses dan urin. Sebaliknya protein pada pakan RB yang berasal dari kombinasi rumput campuran lebih tahan terhadap degradasi, dimana komponen ammonia (nitrogen) lebih sedikit yang terbuang melalui feses dan urin. Jadi, sekalipun jumlah konsumsi protein dari kedua pakan perlakuan ini hampir sama, tetapi karena $\mathrm{N}$ yang terbuang melalui feses lebih besar pada pada $\mathrm{RB}$, maka berdampak pada nilai koefisien cerna pakan.

Nilai kecernaan protein yang dilaporkan Christiyanto et al. (2005) lebih rendah dari hasil penelitian ini, yaitu $68,94 \%-76,50 \%$. Hasil ini diperoleh dari percobaan ransum perlakuan berbasis rumput raja dengan proporsi penggunaan konsentrat $45 \%$ pada sapi perah. de Carvalho et al. (2010) bahkan melaporkan nilai kecernaan protein pakan pada sapi PO lebih rendah dari hasil penelitian Christiyanto et al. (2005). Tingginya nilai kecernaan dalam penelitian ini, disebabkan karena kandungan serat kasar dari konsentrat pakan lengkap masih lebih rendah $(11,23 \%)$ dibanding dengan kandungan serat kasar konsentrat yang digunakan kedua peneliti tersebut, yaitu masing-masing $25,32 \%$ dan $28,90 \%$. Meningkatnya serat kasar dalam ransum, berdampak pada aktivitas pencernaan pregastrik, juga meningkatnya laju pakan dalam saluran cerna pasca lambung, mengurangi kecernaan protein pakan.

Seperti yang dikemukakan beberapa peneliti protein yang masuk ke dalam rumen terdiri dari protein murni dan nitrogen bukan protein (NPN), dimana akan mengalami degradasi menjadi peptidapeptida dan asam-asam amino, yang akan menghasilkan produk akhir berupa amonia $\left(\mathrm{NH}_{3}\right)$, disamping produk-produk lainnya seperti VFA dan $\mathrm{CO}_{2}$ (Ørskov, 1992). Selanjutnnya ammonia $\left(\mathrm{NH}_{3}\right)$ yang terbentuk dalam rumen oleh mikroba akan disintesa menjadi protein mikroba, menggunakan kerangka karbon yang merupakan hasil fermentasi karbohidrat. Protein mikroba inilah yang menjadi sumber utama bagi ternak ruminansia (McDonald et al., 2010; Nolan dan Dobos, 2005) menyatakan bahwa mikroba rumen memiliki kemampuan untuk melakukan sintesis de novo asam-asam amino essensial untuk pembentukan jaringan tubuh hewan inang, dimana sintesis in menggunakan produk-produk ammonia dan kerangka karbon yang diproduksi selama proses degradasi pakan.

\section{Kecernaan energi in vivo}


Nilai kecernaan energi yang diperoleh dalam penelitian ini, yaitu 83,48 dan $87,46 \%$ seperti tercantum pada Tabel 5 . Analisis satatistik menunjukkan bahwa pakan nilai kecernaan energi pakan $\mathrm{RB}$ berbeda lebih tinggi $(\mathrm{P}<0,05)$ dari pakan RA.

Konsumsi energi brutto sapi PO dari pakan RA dan RB masing-masing 3747 dan 3639 Kkal per ekor per hari. NRC (2000) merekomendasikan kebutuhan energi netto untuk sapi potong dengan bobot badan antara $200-300 \mathrm{~kg}$, berkisar antara 3210 - $3680 \mathrm{Kkal} / \mathrm{kg}$ pakan per ekor per hari. Jika di konversi nilai energi brutto pakan RA dan RB ke dalam energi netto menjadi 2998 dan 2911 Kkal. Untuk jenis sapi lokal PO jumlah energi yang dikonsumsi terbilang cukup.

Nilai kecernaan energi kedua pakan percobaan (Tabel 5) terbilang cukup tinggi. Hal ini dimungkinkan karena proporsi penggunaan konsentrat dalam ransum cukup tinggi, yaitu $50 \%$ atau $3,5 \mathrm{~kg}$ dari keseluruhan susunan pakan lengkap. Konsentrat zat-zat nutrien, seperti pati, protein, lemak dan mikro nutrien lebih mudah dicerna dibanding sumber-sumber hijauan, sehingga dalam susunan pakan lengkap nutrien yang tersedia mampu mendukung pertumbuhan dan aktivitas mikroba rumen dalam proses fermentasi serta dapat memberi efek positif bagi pertumbuhan ternak.

Perbedaan nilai kecernaan energi antara pakan RA dan RB disebabkan oleh perbedaan nilai $\mathrm{KCBK}, \mathrm{KCBO}$ dan $\mathrm{KCP}$ kedua pakan tersebut. Nilai KCBK, KCBO, dan KCP pakan RA rata-rata lebih rendah dari pakan RB, yaitu secara berturut-turut $77,05,78,64$ dan $82,13 \%$, sedangkan pakan $\mathrm{RB}$ nilai kecernaan secara berturut-turut $80,15,83,44$ dan $85,55 \%$.

\section{Pertambahan bobot badan dan konversi pakan}

Pengaruh perlakuan pakan lengkap terhadap pertambahan bobot badan sapi disajikan pada Tabel 6. Rataan pertambahan bobot badan yang dihasilkan dari pemberian pakan percobaan menunjukkan hasil yang berbeda. Berdasarkan analisis statistik pakan RA

Tabel 6. Rataan pertambahan bobot badan dan konversi pakan

\begin{tabular}{lcc}
\hline \multirow{2}{*}{ Variabel } & \multicolumn{2}{c}{ Perlakuan } \\
\cline { 2 - 3 } & $\mathrm{RA}$ & $\mathrm{RB}$ \\
\hline Pertambahan bobot badan $(\mathrm{kg})$ & $0,60^{\mathrm{b}}$ & $0,65^{\mathrm{a}}$ \\
Konversi & 0,11 & 0,11 \\
\hline
\end{tabular}

Keterangan: Superskrip yang berbeda pada baris yang sama menunjukkan perbedaan nyata $(\mathrm{P}<0,01)$ 
memberikan hasil berbeda sangat nyata $(\mathrm{P}<0,01)$ lebih rendah dari pakan RB. Hasil penelitian ini hampir memenuhi rekomendasi Rayburn (2009) yang menyatakan bahwa sapi betina dan pejantan muda yang sedang tumbuh dengan pemenuhan kebutuhan bahan kering antara 4,9 - 6,7 kg per ekor per hari dapat menghasilkan $\mathrm{PBB}$ rata-rata $0,70 \mathrm{~kg}$ per hari. Pada penelitian ini nilai konsumsi seperti pada Tabel 4 adalah adalah 5,39 pada RA dan 5,77 kg/ekor/hari untuk RB. Dengan nilai konsumsi ini dapat menghasilkan PBB 0,60 kg untuk RA dan 0,65 kg/ekor/hari dengan nilai konversi pakan rata-rata 0,11 untuk $\mathrm{RA}$ dan $\mathrm{RB}$, ini artinya bahwa $1 \mathrm{~kg}$ pakan yang dikonsumsi baik RA ataupun RB menghasilkan PBB sekitar $0,11 \mathrm{~kg} / \mathrm{ekor} /$ hari. Hasil ini ternyata lebih rendah dari penelitian Aditia et al. (2013), dimana dalam percobaan pemberian pakan lengkap berbasis sorghum silase dengan penggunaan kosentrat $27 \%$ memperoleh PBB sapi PO rata-rata 0,797 kg/ekor/hari. Setiawan dan Nuraini (2016) melaporkan angka PBB sapi PO yang lebih tinggi, yaitu $0,73-1,00 \mathrm{~kg} / \mathrm{ekor} / \mathrm{hari}$. Mereka menggunakan pakan lengkap berbasis rumput lapang $40 \%$ dan susunan konsentrat menggunakan murbei 20\%.Lebih rendahnya PBB dalam penelitian ini kemungkinan disebabkan oleh penggunaan sumber-sumber bahan pakan penyusun yang terbilang masih kurang. Disamping itu, penggunaan ternak sapi PO yang terlalu beragam, baik dari segi umur, maupun bobot badan awal, disamping kondisi genetik, yang perlu diteliti lebih lanjut.

\section{KESIMPULAN}

Pakan lengkap yang berbasis hijauan tebon jagung dan rumput campuran dapat digunakan sebagai pakan standar untuk penggemukan sapi potong lokal karena mampu memenuhi kecernaan nutrien yang tinggi dan nilai konversi pakan yang baik.

\section{DAFTAR PUSTAKA}

Aditya, E. L., R. Priyanto, M. Baihaqi, B.W. Putra, dan M. Ismail. 2017. Performa produksi sapi bali dan peranakan ongole yang digemukan dengan pakan berbasis sorghum. Jurnal Ilmu Produksi dan Teknologi Hasil Peternakan 1(3): 155-159

Christiyanto, M., M. Soejono, R. Utomo, H. Hartadi, dan B.P. Widyobroto. 2005. Konsumsi dan kecernaan nutrien ransum yang berbeda prekursor protein-energi dengan pakan basal rumput raja pada sapi perah. J. Indon. Trop. Anim. Agric. 30(4): 242-247

Derrick, B., B. Russ, D. Toher, dan P. White. 2017. Test statistics for the comparison of means for two 
samples that include both paired and independent observations. Journal of Modern Applied Statistical Methods 16(1): 137157.

de Carvalho, M.C., Soeparno, dan N. Ngadiyono. 2010. Pertumbuhan dan produksi karkas sapi peranakan ongole dan simmental peranakan ongole jantan yang dipelihara secara feedlot. Buletin Peternakan 34(1): 38-46

Heuzé V. dan G. Tran. 2015. Guinea grass (Megathyrsus maximus). Feedipedia, a programme by INRA, CIRAD, AFZ and FAO. https://www.feedipedia.org/node/4 16

Diakses Tanggal 12 Oktober 2019

Nolan, J.V. dan R.C. Dobos. 2005. Nitrogen transactions in ruminants. In: Quantitative Aspects of ruminant Digestion and Metabolism. $2^{\text {nd }}$ Edition. $C A B$ International. Wallingford, UK. p. 137

NRC. 2000. Nutrient Requirements of Beef Cattle: $7^{\text {th }}$ Revised ed. Washington, DC: The National Academies Press.

Orskov, E.R., C. Fraser, dan I. McDonald. 1972. The effects of urea on digestion, nitrogen retention and growth in young lambs. Br. J. Nutr. 27(3): 491-501.

Ørskov, E.R. 1992. Protein Nutrition in Ruminants. 2nd Edition. Academic Press. New York, EUA.

Pathak, A.K. 2008. Various factors affecting microbial protein synthesis in the rumen. Veterinary World. 1(6): 186-189
Rayburn, E.B. 2009. Nutrient Requirements for Beef Cattle. Forage Management West Virginia University Extension Service.

Rodríguez, R., A. Sosa, dan Y. Rodríguez. (2007). Microbial protein synthesis in rumen and its importance to ruminants. Cuban J. Agric. Sci. 41(4): 287-294.

Satter, L.D. dan L.L. Slyter. 1974. Effect of ammonia concentration on rumen microbial protein production in vitro. Br. J. Nutr. 32:199-208

Schmidt, J. dan E. Zsédely. 2011. Nutrition of Ruminants. University of WestHungary. Hungary

Setiawan, D. dan H. Nuraini. 2016. Penampilan produksi sapi Peranakan Ongole yang diberi pakan konsentrat yang mengandung tepung daun murbei. Jurnal Agripet 16(1): 16-22

Snedecor, G.W. dan W.G. Cochran. 1989. Statistical Methods, Eighth Edition, Iowa State University Press.

Sutardi, T. 2003. Peningkatan Produksi Ternak Ruminansia Melalui Amoniasi Pakan Serat Bermutu Rendah, Defaunasi dan Suplementasi Sumber Protein Bahan Degradasi Dalam Rumen. Laporan Penelitian. Fakultas Peternakan Institut Pertanian Bogor, Bogor.

Van Soest, P.J. 1994. Nutritional Ecology of the Ruminant. Cornell University Press. Ithaca, NY. p. 261

NRC. 2000.Nutrient Requirements of Beef Cattle: $7^{\text {th }}$ Revised ed. Washington, DC: The National Academies Press. 